\title{
A Comparative Study of Serum Ast/Sgot Levels Among the Patients of Thyroid Disorders
}

\author{
Gulab Kanwar ${ }^{1}$, Monika Shekhawat ${ }^{2 *}$, Mahesh Chandra Mehra ${ }^{3}$, Neeraj Saxena ${ }^{4}$ \\ ${ }^{1,2}$ Prof. And Head, Biochemistry Department, GMC, Kota (Rajasthan) \\ ${ }^{3,4}$ Residents, Biochemistry Department, GMC, Kota (Rajasthan)
}

\begin{abstract}
:
Background: Thyroid dysfunction is one of the most common endocrinological disorders. Consequently, abnormalities of these hormones frequently involve many organ systems producing diverse clinical signs and symptoms which are generally nonspecific. Thus confirmation of a provisional diagnosis of thyroid disorder rests largely upon the biochemical parameters. Aspartate transaminase (AST) is an enzyme found in nearly all living cells.
\end{abstract}

Aim: This study is conducted to see the effects of variation in thyroid hormones on the Aspartate transaminase (AST) levels, thus elucidating the effect on numerous systems of the body. The study was conducted in the Government Medical College and associated group of Hospitals, Kota (Rajasthan), India. The duration of study was January 2016 to October 2016. The present study comprised of 150 subjects, out of which 50 were hypothyroid and 50 cases of hyperthyroidism and 50 were euthyroid subjects. The statistical analysis was performed by using Microsoft Excel Program.

Results: Among the total 150 subjects included in the study, there were 45 males and 105 females. On the basis of Serum T3, T4 and TSH levels, the subjects were categorised into hypothyroid, hyperthyroid and euthyroid. The Mean $\pm S D$ of Serum AST levels in hypothyroid, hyperthyroid and euthyroid subjects is $64.28 \pm 10.56$, $52.08 \pm 8.62$ and $20.06 \pm 8.64$ respectively. The results were compared by one - way ANOVA. The P value was calculated and found $<0.05$, which was considered statistically significant.

Conclusion: This study shows the raised levels of AST were seen in hypothyroid and hyperthyroid cases as compared to euthyroid subjects, though the rise is significant in the hypothyroid cases.

Keywords: Aspartate transaminase (AST) ,Euthyroid, Hyperthyroid, Hypothyroid, Serum Glutamate Oxaloacetate Transaminase (SGOT).

\section{Introduction}

Thyroid gland is one of the largest endocrine gland of the body, located in the neck, anterior to trachea. It consists of two lobes that are connected by an isthmus, which secretes the hormones tetraiodothyronine or thyroxine $\left(\mathrm{T}_{4}\right)$ and triiodothyronine $\left(\mathrm{T}_{3}\right)$. The production of $\mathrm{T}_{4}$ and $\mathrm{T}_{3}$ is tightly regulated through the hypothalamic-pituitary-thyroid axis [1]. Thyroid disorders are commonly separated into two major categories, hypothyroidism (due to poorly functioning thyroid gland) and hyperthyroid(caused by overactive thyroid gland)[2].The gland produces hormones which play a great role in control of basal metabolic rate (BMR), general body metabolism, growth, development and tissue differentiation. Thyroid dysfunction is one of the most common endocrinological disorders. Consequently, abnormalities of these hormones frequently involve many organ systems producing diverse clinical signs and symptoms which are generally nonspecific. Thus confirmation of a provisional diagnosis of thyroid disorder rests largely upon the biochemical parameters [3] The commonly used parameters for assessment of thyroid function are estimation of thyroid stimulating hormone (TSH), total tri-iodothyronine (T3), total thyroxine (T4), free T3 (FT3) and free T4 (FT4). Out of these TSH has been accepted as the initial screening test. This is because serum level of TSH has been documented to reflect the integrative action of thyroid hormone on the tissue most sensitive to circulating thyroid hormones, the pituitary [4].

Thyroid disease is quite common. Current estimates suggest that it affects as many as $9 \%$ to $15 \%$ of the adult female population and a smaller percentage of adult males [5].This gender-specific prevalence almost certainly results from the underlying autoimmune mechanism for the most common forms of thyroid disease, which include both Graves' and Hashimoto's disease [6]. However, with advancing age, especially beyond the eighth decade of life, the incidence of disease in males rises to be equal to that of females [5]. Thyroid disorders being the most common disorders of endocrine system, require essential and timely diagnosis [7]. The prevalence of both hypothyroidism and hyperthyroidism increases with age, showing a higher incidence in women than in men $[8,9]$. Thyroid hormones exert their effect on cardiovascular hemodynamic by genomic and non-genomic actions $[10,11]$. 
The significance of the contribution of laboratory medicine to clinical cardiology has grown in importance over years [12]. Clinicians have used biomarkers as an additional tool to aid clinical assessment and to enhance their ability to identify the "vulnerable" patient at the risk for cardiovascular diseases, as suggested by a recent National Institute of Health panel (NIH) [13,14].Aspartate transaminase (AST) or aspartate aminotransferase, also known as AspAT/ASAT/AAT or serum glutamic oxaloacetic transaminase (SGOT), is a pyridoxal phosphate (PLP)-dependent transaminase enzyme (EC 2.6.1.1) that was first described by Arthur Karmen and colleagues in 1954.AST catalyzes the reversible transfer of an $\alpha$-amino group between aspartate and glutamate and, as such, is an important enzyme in amino acid metabolism. AST is found in the liver, heart, skeletal muscle, kidneys, brain, and red blood cells. Serum AST level, serum ALT (alanine transaminase) level, and their ratio (AST/ALT ratio) are commonly measured clinically as biomarkers for liver health. The tests are part of blood panels.AST is found in the liver, heart (cardiac muscle), skeletal muscle, kidneys, brain, and red blood cells.AST may be elevated also in diseases affecting other organs, such as myocardial infarction, acute pancreatitis, acute hemolytic anemia, severe burns, acute renal disease, musculoskeletal diseases, and trauma [15-17].

\section{Aim Of The Study}

This study is conducted to see the effects of variation in thyroid hormones on the SGOT/AST levels, thus elucidating the effect on various systems of the body. This study may be beneficial for public health and clinical practice

\section{Objectives Of The Study}

1. To estimate Serum T3, T4 and TSH in all subjects.

2. To categorize all the subjects into hypothyroid cases, hyperthyroid cases and euthyroid controls.

3. To estimate the SGOT/ AST (Serum Glutamate Oxaloacetate Transaminase/ Aspartate Transaminase) in all the subjects.

\section{Place Of Study}

\section{Material And Methods}

The study was performed in the Government Medical College and associated group of Hospitals, Kota (Rajasthan), India. The duration of study was January 2016 to October 2016.

\section{Sample Size}

The present study comprised of 150 subjects, out of which 50 were hypothyroid and 50 cases of hyperthyroidism and 50 were euthyroid subjects, which will act as control subjects. The subjects were selected amongst those attending outdoor and indoor in NMCH, Kota, Rajasthan, India.

\section{Sample Collection And Storage}

All samples were taken from hypothyroid, hyperthyroid and euthyroid subjects who fasted for at least 8 hours before the blood collection. $7 \mathrm{ml}$ venous blood will be drawn from each subject \& discharged into a plain sample bottle and allowed to clot. Sample is centrifuged at $3000 \mathrm{rpm}$ for $15 \mathrm{~min}$, serum separated from cells, and stored at $2-8^{0} \mathrm{C}$ in stoppered tubes for up to 48 hours. If longer storage is required, the sera or plasma is frozen at $-25 \pm 6^{\circ} \mathrm{C}$. Serum separated and analyzed for $\mathrm{T}_{3}, \mathrm{~T}_{4}$, TSH, CK-NAC, CK-MB, LDH and AST(SGOT) . The sample were processed in standardized manner under set protocol in the Department of Biochemistry, central lab NMCH, Kota.

\section{Statistical Analysis}

The statistical analysis was performed by using Microsoft Excel Program. The results were expressed as MEAN \pm STANDARD DEVIATION. The P value was calculated and found $<0.05$, which was considered statistically significant. The results were compared by one - way ANOVA between hyperthyroid, hypothyroid, and euthyroid cases.

\section{Subject Selection}

\section{Inclusion Criteria:-}

a. >25years and $<50$ years

b. Newly diagnosed cases of hypothyroidism and hyperthyroidism.

\section{Exclusion Criteria:-}

1. pregnancy

2. hypertension and diabetes mellitus

3. chronic renal disorders and liver disorders

4. cardiac disorders

5. dehydration

6. glomerulonephritis and pyelonephritis

7. eclampsia \& preeclampsia 
8. Patients on certain medications -antiarrhythmics, $\beta$-blockers, lithium, fibrates, phenothiazines, steroids, statins and, corticosteroids etc.

9. age $<25$ years,$>50$ years

10. previous use of L-thyroxine or antithyroid medication and thyroidectomy.

11. Drug intoxication,

12. Patients not willing to participate in the study.

* Informed consent was obtained from each subject.

\section{Results And Observations}

Table 1: Distribution Of Subjects In Different Age Groups

Among the total of 150 subjects of ages 25 -50 years of both sexes were included in the study, 50 were hypothyroid, 50 were hyperthyroid and 50 were euthyroid. Their serum levels of T3, T4 and TSH were estimated and confirmed.

Among the total 150 subjects, age wise distribution was done in all the 3 groups (hypothyroid, hyperthyroid and euthyroid). All the subjects were divided in 5 groups :

Group - 1 included ages 25-30 years.

Group -2 included ages 31-35years

Group -3 included ages 36-40years

Group -4 included ages 41 - 45years

Group - 5 included ages 46-50years.

In hypothyroid cases, 5 cases were in group $-1,5$ in group-2, 15 in group-3,18 in group-4 and 7 in group -5. In hyperthyroid cases, 3 cases were in group -1, 5 in group-2, 12 in group-3,13 in group-4 and 17 in group -5. The euthyroid subjects were selected equally in all age groups.

This is shown in Table 1 and Graph 1.

Table 1: Showing distribution of subjects of various thyroid categories in 5 age-groups.

\begin{tabular}{|l|l|l|l|l|}
\hline GROUPS & AGE-GROUPS & $\begin{array}{l}\text { NO. OF OF } \\
\text { HYPOTHYROID } \\
\text { CASES }\end{array}$ & $\begin{array}{l}\text { NO. } \\
\text { HYPERTHYROID } \\
\text { CASES }\end{array}$ & $\begin{array}{l}\text { NO. } \\
\text { EUTHYROID } \\
\text { CASES }\end{array}$ \\
\hline 1 & $25-30$ Years & 5 & 3 & 10 \\
\hline 2 & 31-35Years & 5 & 5 & 10 \\
\hline 3 & $36-40$ Years & 15 & 12 & 10 \\
\hline 4 & $41-45 Y$ Years & 18 & 13 & 10 \\
\hline 5 & $46-50$ Years & 7 & 17 & 10 \\
\hline
\end{tabular}

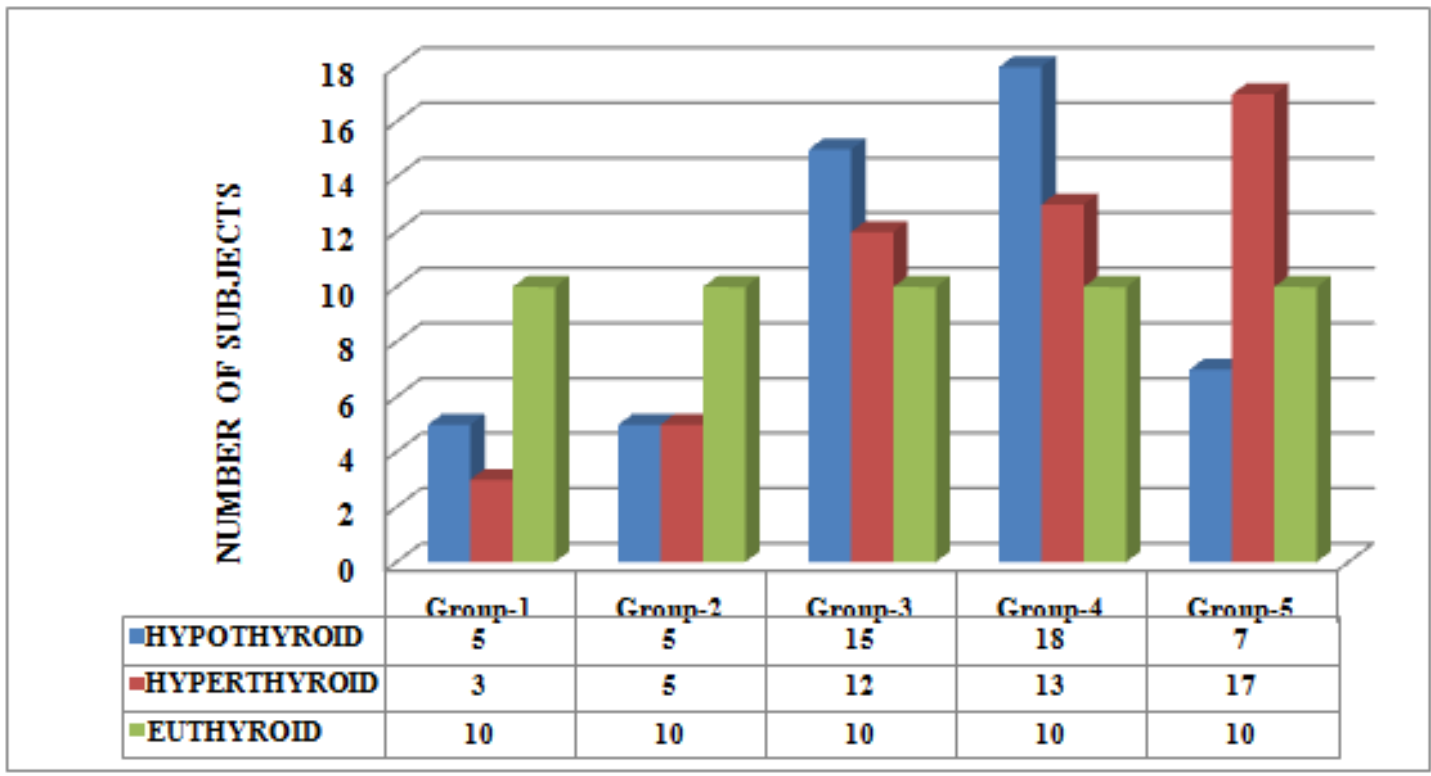

Graph-1: Showing distribution of subjects of various thyroid categories in 5 age-group 
Table 2: Mean Of Ages

The Mean $\pm \mathrm{SD}$ of ages in hypothyroid, hyperthyroid and euthyroid subjects is $39.48 \pm 6.05,47.57 \pm 6.27$ and $37.66 \pm 7.48$ respectively.

The data is as shown below:

Table 2: Showing Mean \pm SD of Ages In Hypothyroid, Hyperthyroid And Euthyroid Subjects.

\begin{tabular}{|c|c|c|c|}
\hline $\begin{array}{c}\text { THYROID } \\
\text { CATEGORIES }\end{array}$ & HYPOTHYROID & HYPERTHYROID & EUTHYROID \\
\hline AGE(MEAN \pm SD) & $39.48 \pm 6.05$ & $47.57 \pm 6.27$ & $37.66 \pm 7.48$ \\
\hline
\end{tabular}

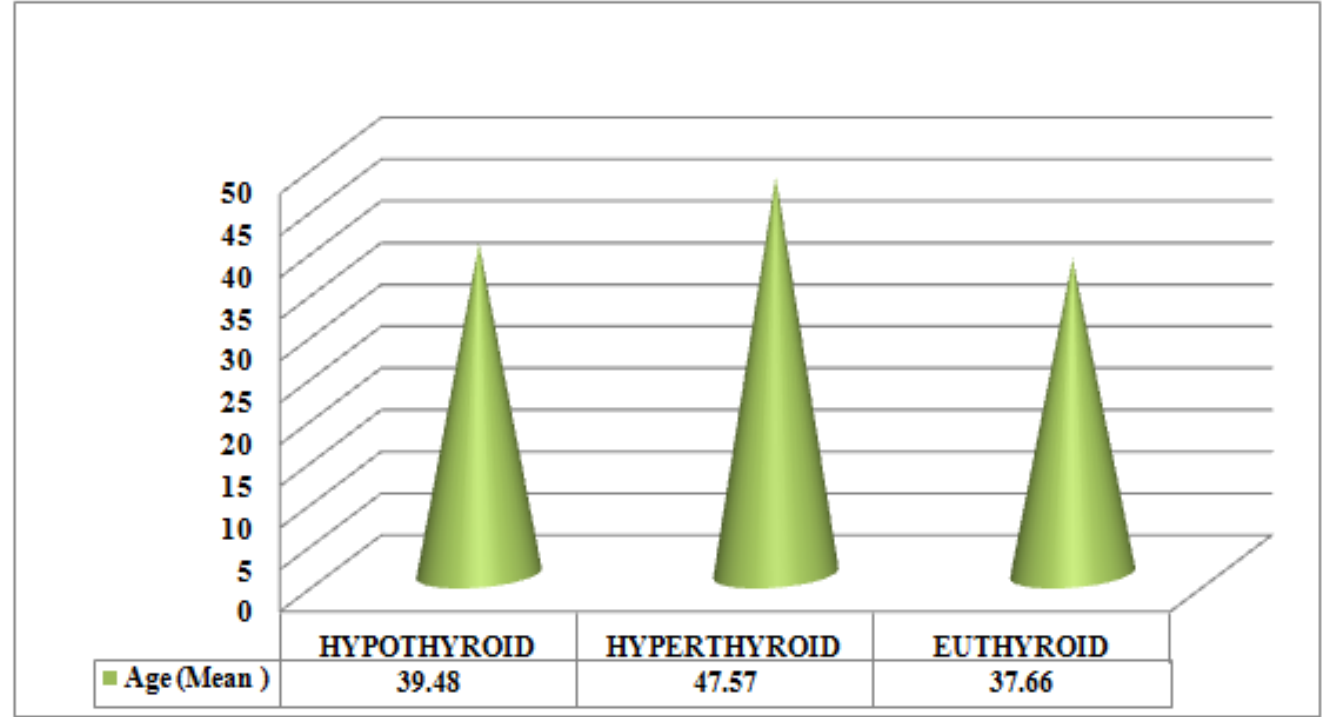

Graph 2: Showing Mean of Ages In Hypothyroid, Hyperthyroid And Euthyroid Subjects.

Table 3: Gender Distribution Of The Subjects

Among the total 150 subjects included in the study, there were 45 males and 105 females(as shown in table 3 and Figure 3 given below).

Table 3: Showing the distribution of patients according to gender

\begin{tabular}{|l|l|}
\hline GENDER & NUMBER \\
\hline FEMALES & 105 \\
\hline MALES & 45 \\
\hline TOTAL & 150 \\
\hline
\end{tabular}

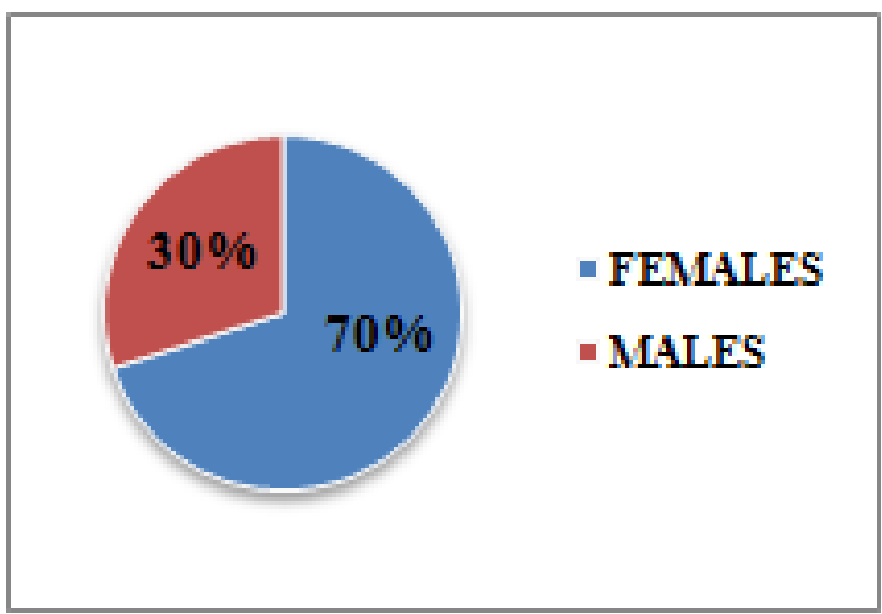

Figure 3: Pie diagram showing distribution of patients according to gender 
Table 4: Mean \pm Sd Of Serum Ast/Sgot Levels In Different Thyroid Categories

The Mean \pm SD of Serum AST/SGOT levels in hypothyroid, hyperthyroid and euthyroid subjects is $64.28 \pm$ $10.56,52.08 \pm 8.62$ and $20.06 \pm 8.64$ respectively.

The statistical analysis is done by one-way ANOVA. P-value is found to be $<0.05$, which is significant as shown below in Table 4.

Table 4: Showing the Mean \pm SD of Serum LDH levels in hypothyroid, hyperthyroid and euthyroid subjects.

$*$ P-value is $<0.05$, which is significant.

\begin{tabular}{|l|l|l|l|l|}
\hline PARAMETER & HYPOTHYROID & HYPERTHYROID & EUTHYROID & P-value \\
\hline $\begin{array}{l}\text { AST/SGOT (IU/L) } \\
(\text { Mean } \pm \text { SD) }\end{array}$ & $64.28 \pm 10.56$ & $52.08 \pm 8.62$ & $20.06 \pm 8.64$ & $<0.05^{*}$ \\
\hline
\end{tabular}

The mean of serum LDH levels in hypothyroid, hyperthyroid and euthyroid subjects is depicted graphically below in the graph 4 .

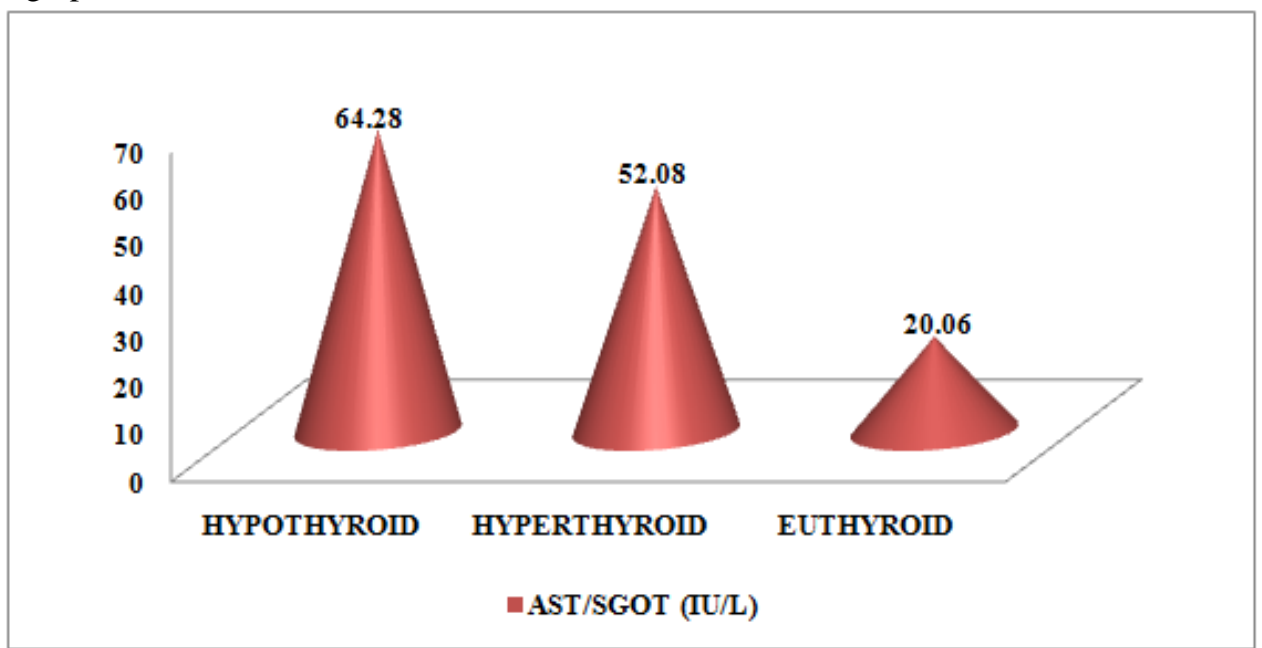

Graph 4: Showing the Mean =of Serum AST/SGOT levels in hypothyroid, hyperthyroid and euthyroid subjects.

Table 5: Showing Mean \pm Sd Of Serum T3, T4, Tsh And Ast/Sgot Among Hypothyroid, Hyperthyroid And Euthyroid Subjects.

\begin{tabular}{|c|c|c|c|c|}
\hline PARAMETERS & HYPOTHYROID & HYPERTHYROID & EUTHYROID & p-value \\
\hline T3 (ng/ml) & $0.4 \pm 0.2$ & $2.4 \pm 0.4$ & $1.13 \pm 0.37$ & $<0.05$ \\
\hline T4( $\mu \mathrm{g} / \mathrm{dl})$ & $3.2 \pm 1.7$ & $16.04 \pm 2.92$ & $8.63 \pm 1.64$ & $<0.05$ \\
\hline TSH $(\mu \mathrm{IU} / \mathrm{dl})$ & $26.04 \pm 10.44$ & $0.04 \pm 0.06$ & $3.02 \pm 1.26$ & $<0.05$ \\
\hline AST/SGOT (IU/L) & $64.28 \pm 10.56$ & $52.08 \pm 8.62$ & $20.06 \pm 8.64$ & $<0.05$ \\
\hline
\end{tabular}

*P-value is $<0.05$, which is significant

\section{Discussion}

Overt abnormalities in thyroid function are common endocrine disorders affecting 5-10\% of individuals over a lifespan.[18] Clinical symptoms and signs are often nonspecific, and the diagnosis and monitoring of therapy depends crucially on measurements of thyroid hormones (triiodothyronine, T3 and thyroxine, T4), and thyroid stimulating hormone (TSH) in blood[19]. The present study was undertaken to understand the effects of thyroid disorders on the cardiovascular system, which has been demonstrated by the use of thyroid hormones(T3, T4 and TSH) and AST/SGOT.The study was conducted in the Government Medical College and associated group of Hospitals, Kota (Rajasthan), India. The duration of study was January 2016 to October 2016. The study included 150 subjects, amongst which 50 were hypothyroid, 50 were hyperthyroid cases and 50 were euthyroid subjects.

Thyroid disorders cause remarkable systemic derangements, because signs and symptoms referable are the manifestations of thyroid dysfunctions. Significantly thyroid hormones play crucial role in differentiation, growth and metabolism. TH has important tissue effects, which are classified into three major aspects: general thermo genesis, mediated by increase the basal metabolic rate; general metabolic effects, mediated by stimulating protein and lipid turnover and carbohydrate metabolism; and effects on growth and development[20]. Thyroid diseases are, arguably, among the commonest endocrine disorders worldwide. India too, is no exception. According to a projection from various studies on thyroid disease, it has been estimated that about 42 million people in India suffer from thyroid diseases [21]. In the population-based study done in Cochin 
on 971 adult subjects, the prevalence of hypothyroidism was $3.9 \%$. In women, the prevalence was higher, at $11.4 \%$, when compared with men, in whom the prevalence was $6.2 \%$. The prevalence of hyperthyroidism has been studied in several studies. In an epidemiological study from Cochin, subclinical and overt hyperthyroidism were present in $1.6 \%$ and $1.3 \%$ of subjects participating in a community survey [22].

In the present study, among the total 150 subjects, the number of females(105) were found to be more as compared to the males(45), as observed in Table 3.Among hypothyroid (38 females and 12 males) and hyperthyroid (32 females and 18 males) cases (shown in Table 4) the number of females were found to be more than number of males, which is in accordance with previous studies.Thus showing that the thyroid disorders are more prevalent among the females as compared to males. Saima Mustaq et al. (2014) also did the same, where $80 \%$ females and $20 \%$ males were included in the study [23]. Earlier studies also have suggested that thyroid disorders are more common in women than men. The higher prevalence of thyroid disease in women suggests that estrogen might be involved in pathophysiology of thyroid dysfunction.Estradiol has an antagonistic effect on the hormones T3 and T4.The reason is estradiol competes with T3 and T4 for binding sites on the receptor proteins[24].

Hypothyroidism is characterized by low circulating thyroid hormones and raised TSH levels. In this study, the Mean \pm SD of serum T3, T4 and TSH levels are 0.4 $\pm 0.2,3.2 \pm 1.7$ and $26.04 \pm 10.44$ respectively. Hyperthyroidism is characterized by high circulating thyroid hormones and decreased TSH levels. In this study, the Mean \pm SD of serum T3, T4 and TSH levels are $2.4 \pm 0.4,16.04 \pm 2.92$ and $0.04 \pm 1.26$ respectively. We found that these all differences are statistically significant $(\mathrm{p}<0.05)$, as seen in Table 5. Only a few studies have investigated serum AST/SGOT activity in patients with thyroid dysfunction.[25,26]. In this study, AST was studied as an indicator of numerous systemic disorders, due their indispensible role in the efficient functioning of body and maintaining its normal physiological activities. The Mean \pm SD of Serum AST levels in hypothyroid, hyperthyroid and euthyroid subjects is $64.28 \pm 10.56,52.08 \pm 8.62$ and 20.06 \pm 8.64 respectively. Raju Pandey et al. (2013), studied the assessment of Serum Enzymes Levels in patients with thyroid alteration. Thyroid hormones exert their effect on all tissue and modulate the rate of metabolic activity. Alterations in thyroid function can affect the various organ system of body and perturb measures like AST, ALT, GGT, ALP, CPK and LDH. Both hypothyroidism and hyperthyroidism have potentially fatal systemic manifestations. In conclusion, conducted study demonstrated that there is a positive association between increased serum AST, ALT, GGT, CPK, ALP and LDH in hyperthyroidism and hypothyroidism [27].

\section{Conclusion}

The present study was designed to evaluate the changes in Serum SGOT levels in the patients of thyroid disorders. A total number of 150 samples have been taken and among these, there were 45 males and 105 females. Personal information was recorded in a specially designed form and overnight fasting venous blood samples were collected and analyzed studied parameters which have been mentioned earlier. It has been seen that there is a change of Serum SGOT levels in hypothyroid and hyperthyroid patient. This finding shows that Serum SGOT levels are raised more in hypothyroid cases than hyperthyroid cases. Thus, patients with hypothyroidism are at greater risk of developing systemic disorders. Although the multiple biochemical abnormalities in hypothyroidism and hyperthyroidism are well defined, their underlying patho-physiology is not entirely understood.This study may be helpful in public health and clinical practice, as both thyroid disorders and cardiovascular diseases both are important issue of concern to reduce the morbidity and mortality and to reduce DALY (Disability Adjusted Life Years).

\section{References}

[1]. Danzi S, Klein I. Thyroid hormone and the cardiovascular system. Minerva Endocrinologica. 2004;29: 139 -150

[2]. Kahaly GJ, Dillmann WH. Thyroid hormone action in the heart. Endocrine Rev. 2005;26:704 -728.

[3]. Saha M, Sarkar P, Chattopadhyay R, Mukhopadhyaya M, Bhowmick K. Role of creatine kinase and its coenzymes as surrogate markers of thyroid function. IJMB 2009;13(2): 10-4.

[4]. Spencer CA. Strategy for use of serum thyrotrophin vs. free thyroxine measurement in thyroid testing. AACC Endo 1991;10:9-17.

[5]. Canaris GJ, Manowitz NR, Mayor G, Ridgway EC. The Colorado thyroid disease prevalence study. Arch Intern Med. 2000;160:526 -530 .

[6]. Volpe R. Immunoregulation in autoimmune thyroid disease. Thyroid. 1994;4:373-377.

[7]. Hollowell JG, Staehling NW, Flanders WD, Honnon WH, Gunter EW, Spencer CA, et al. Serum TSH, T(4), and thyroid antibodies in United States population(1988 to 1994): National Health and Nutrition Examination Survey(NHANES III).J Clin Endocrinol Metabol. 2002;87: 489-99.

[8]. Sawin CT, Castelli WP, Hershman JM, McNamara P, Bacharach P. The aging thyroid, Thyroid Deficiency and the Framingham Study. Arch intern Med.1985; 145:1386-8.

[9]. Preveen Kumar and Micheal Clark.Endocrine Disease-Thyroid dysfunctions. “ Essentials of Clinical Medicine”. Elsevier publications. $5^{\text {th }}$ edition.619-629.

[10]. Kahaly GJ. Dillman WH.Thyroid action on the heart.Endocr Rev.2005;26:704-28

[11]. Davis PJ,Davis FB.Non-genomics actions of thyroid hormone on the heart.Thyroid.2002;12:459-66.

[12]. Gharib H, Tuttle RM, Baskin HJ, Fish LH, Singer PA,McDermott MT.Subclinical thyroid dysfunction: a joint statement from the American Association of Clinical Endocrinologists. The American thyroid Association, the Endocrine Society.J Clin Endocrinol Metab.2005;12:483-7. 
[13]. Clerico A. The increasing impact of laboratory medicine on clinical cardiology. Clin Chem Lab Med 2003;41:871-83.

[14]. Naghavi M, Libby P, Falk E, Casscells SW, Litovsky S, Rumberger J, Badimon JJ, Stefanadis C, Moreno P, Pasterkamp G, Fayad Z, Stone PH, Waxman S, Raggi P, Madjid M, Zarrabi A, Burke A, Yuan C, Fitzgerald PJ, Siscovick DS, de Korte CL, Aikawa M, Juhani Airaksinen KE, Assmann G, Becker CR, Chesero JH, Farb A, Galis ZS, Jackson C, Jang JK, Koenig W, Lodder RA, March K, Demirovic J, Navab M,Priori SG, Rekhter MD, Bahr R, Grandy SM, Mehran R, Colombo A, Boerwinkle E, Ballantyne C, Faxon DP, Kaul S, Drexler H, Greenland P, Muller JE, Virmani R, Ridker PM, Zipes DP, Shah PK, Willerson JT. From vulnerable plaque to vulnerable patient: a call for new definations and risk assessment stratergies: part I. Circulation.2003;108: 1664-1672.

[15]. KARMEN, A; WROBLEWSKI, F; LADUE, JS (January 1955). "Transaminase Activity In Human Blood.". The Journal Of Clinical Investigation. 34 (1): 126-31. Doi:10.1172/Jci103055.PMC 438594 ङ. PMID 13221663.

[16]. KARMEN, A (January 1955). "A Note On The Spectrometric Assay Of Glutamic-Oxalacetic Transaminase In Human Blood Serum.". The Journal Of Clinical Investigation. 34 (1): 131-3.PMC 438594 ङ. PMID 13221664.

[17]. LADUE, JS; WROBLEWSKI, F; KARMEN, A (24 September 1954). "Serum Glutamic Oxaloacetic Transaminase Activity In Human Acute Transmural Myocardial Infarction.". Science. 120 (3117): 497-9. doi:10.1126/ Science.120. 3117.497. PMID 13195683.

[18]. Vanderpump MP, Tunbridge WM. The epidemiology of thyroid diseases. In: Bravermann LE, Utiger RD, editors. Werner and Ingbar's the thyroid: A fundamental and clinical text. Philadelphia: Lippincott-Raven Publishers; 2000. p. 467-73.

[19]. Jarlov AE, Nygaard B, Hegedus L, Hartling SG, Hansen JM. Observer variation in the clinical and laboratory evaluation of patients with thyroid dysfunction and goiter. Thyroid 1998;8:393-8.

[20]. Vargas U Hernando and Morales S Eliana."Role of Thyroid Hormones in Different Aspects of Cardiovascular System".Endocrinol Metab Synd 2015,4:2.

[21]. Available from: http://www.ias.ac.in/currsci/oct252000/n\%20 kochupillai.PDF [Last accessed on 2011 April 2].

[22]. Usha Menon V, Sundaram KR, Unnikrishnan AG, Jayakumar RV, Nair V, Kumar H. High prevalence of undetected thyroid disorders in an iodine sufficient adult south Indian population. J Indian Med Assoc 2009;107:72-7.

[23]. Saima Mushtaq, Mona A. Tilak, Malik Rameez Rashid, Sarita A. Shinde, Pradnya J. Phalak(2014).Biochemical Evaluation of myopathy in patients of hypothyroidism. Indian Journal of Basic and Applied Medical Research; March 2014: Vol.-3, Issue - 2, P.364-372.

[24]. Vasudevan DM,Shreekumari S,Vaidyanathan K.Textbook of Biochemistry .Jaypee Brothers Medical publisher, $7^{\text {th }}$ edition 2013;664-671

[25]. Griffiths PD. Serum enzymes in diseases of the thyroid gland. J Clin Pathol 1965;18:660-3.

[26]. Roti E, Bandini P, Robuschi G, Emanuele R, Bolognesi R, Ciarlini E, et al. Serum concentrations of myoglobin, creatine kinase, lactate dehydrogenase and cardiac isoenzymes in euthyroid, hypothyroid and hyperthyroid subjects. Ric Clin Lab 1980;10:609-17.

[27]. Raju Pandey, Suresh Jaiswal, Jay Prakash Sah, Krishna Bastola, Subadhra Dulal(2013). Assessment of Serum Enzyme Level in Patients with Thyroid Alteration Attending Manipal Teaching Hospital, Pokhara. A Journal of Life Sciences. Volume 3, Issue 1,1-9. 